\title{
PEMBERDAYAAN MASYARAKAT MELALUI PENINGKATAN MUTU PENDIDIKAN, EKONOMI DAN KESEHATAN STUDI KASUS DESA SITU ILIR
}

\author{
Sutisna $^{1}$, Milah Hikmatin, Dhita Putri Utami ${ }^{2}$ \\ sutisna@fai.uika-bogor.ac.id \\ Dosen Fakultas Agama Islam ${ }^{1}$, Mahasiswa KKN Kelompok 33 Tahun $2018^{2}$
}

\begin{abstract}
ABSTRAK
Kuliah Kerja Nyata merupakan proses pembelajaran mahasiswa melaui sebagai kegiatan langsung ditengah-tengah masyarakat, dan mahasiswa berupaya untuk menjadi bagian dar masyarakat secara aktif dan kreatif terlibat daam dinamika yang terjadi di masyarakat. Mahasiswa mempunyai peran strategis sebagai agen perubahan. Kuliah Kerja Nyata (KKN) adalah salah satu wujud pengabdian mahasiswa kepada masyarakat lewat pemberian bantuan, pemberdayaan, pelatihan, penyuluhan, pendampingan dan untuk menyadarkan potensi yang dimiliki, serta membantu meningkatkan kualitas hidup dan pembangunan. mahasiswa akan mendapatkan kemampuan generatif berupa life keterampilan hidup. Observasi dilakukan dengan metode: (1) Metode Participatory Rural Appraisal (PRA), (2) Pendekatan Sosial, dan (3) melihat ke lapangan secara langsung. Berdasarkan hasil observasi maka ditentukan program kerja KKN kelompok yang akan dilaksanakan meliputi program kelompok fisik dan program kelompok nonfisik. Program kelompok fisik yaitu kerja bakti, jalan sehat dan lainnya, sedangkan program kelompok non fisik yaitu berupa penyuluhan, bimbingan belajar, pendampingan TK, pendampingan posyandu dan yang lainnya. Dilihat dari program, program tersebut maka mahasiswa berperan sebagai fasilitator, dinamisator, dan motivator. Pelaksanaan program kerja yang dimulai sejak tanggal 7 Agustus 2018 - 5 September 2018 ini relatif lancar. Dengan demikian, setelah kegiatan KKN berakhir diharapkan para warga Desa Situ Ilir dapat terus mengembangkan segala potensi yang ada pada dirinya dan alam sekitarnya.
\end{abstract}

Keyword: KKN, Pemberdayaan, Program Kerja.

\section{PENDAHULUAN}

\section{Latar Belakang}

Pemberdayaan ekonomi rakyat adalah usaha untuk menjadikan ekonomi yang kuat, besar, modern dan berdaya saing tinggi dalam mekanisme pasar yang benar. Karena kendala pengembangan ekonomi rakyat adalah kendala structural, maka pemberdayaan ekonomi rakyat harus dilakukan melalui perubahan structural.
Pemberdayaan ekonomi rakyat tidak cukup hanya dengan peningkatan produktivitas, memberi kesempatan berusaha yang sama, atau hanya memberikan suntikan modal sebagai stimulan, tetapi harus dijamin adanya kerjasama dan kemitraan yang erat antara yang telah maju dan yang masih lemah dan belum berkembang agar terciptanya kemaslahatan umat kebijakanya dalam pemberdayaan ekonomi rakyat adalah : 
a. Pemberian peluang atau akses yang lebih besar kepada asset produksi (khususnya modal).

b. Memperkuat posisi transaksi dan kemitraan usaha ekonomi rakyat bukan sekedar price taker.

c. Pelayanan pendidikan dan kesehatan.

d. Penguatan industry kecil.

e. Mendorong munculnya wirausaha baru

Desa situ ilir merupakan salah satu desa yang terletak di kecamatan cibungbulang kabupaten Bogor, Desa situ ilir memiliki lahan pesawahan yang cukup luas, tanah yang subur, wilayah yang asri serta memiliki wisata yang asri, serta memiliki wisata yang alami yang dapat di perdayakan. Dan dalam hal pendidikan Desa situ ilir mendapat penghargaan sebagai Sentral Pendidikan karena diwilayah ini memiliki lembaga pendidikan yang cukup lengkap pada tingkat PAUD, TK, SD/MI, SMP/MTS, MA/SMK/SMA, Sekolah Tinggi bahkan banyak terdapat juga pondok pesantren.

Namun masyarakat Desa Situ ilir ini belum dapat memanfaatkan segala potensi yang ada secara maksimal. Kebanyakan masyarakat bekerja sebagai guru, petani dan sebagian kecil sebagai buruh tani (Petani). Walaupun mendapat gelar sebagai sentral pendidikan, tingkat kesadaran masyarakat dalam memajukan perekonomian desa masih rendah seperti halnya perilaku remaja dan pola piker masyarakat dalam menghadapi situasi tingkat penghasilan yang rendah masih maraknya pengguna Bank Keliling dan simpan pinjam yang tidak sesuai dengan aturan agama hal ini bertolak belakang dengan potensi yang dimiliki oleh Desa Situ Ilir.

Dalam berbagai permasalahan yang dihadapi oleh Desa Situ Ilir tersebut kami memberikan beberapa solusi untuk meningkatkan kesadaran masyarakat dengan diselenggarakanya Sosisalisasi Hukum Penyalahgunaan Narkoba dan pencegahan Pergaulan Bebas serta Sosialisasi Berbasis Ekonomi Syariah dan program-program lainya yang dapat dilakukan oleh masyrakat. Kami juga berusaha memberi motivasi kepada masyarakat, terutama kalangan muda agar menempuh pendidikan yang tinggi. Seluruh program kerja yang dilakukan di Desa Situ Ilir adalah upaya pemberdayaan ekonomi masyarakat demi terciptanya kemaslahatan umat khususnya Masyarakat Desa Situ Ilir.

\section{Analisis Situasi}

Desa Situ Ilir merupakan salah satu desa yang terletak di kecamatan Cibungbulang kabupaten Bogor. Tingkat pendidikan didesa ini sudah cukup baik karena Desa ini disebut juga sebagai Central Pendidikan. Karena lemkap nya lembaga pendidikan dari pendidikan rendah sampai tingkat tinggi, Paud sampai Sekolah Tinggi ada di Desa ini. Namun tetap saja ada dibeberapa wilayah yang masih tidak mementingkan pendidikan meskipun hanya beberapa persen, setelah lulus SMP mereka tidak lanjut lagi sekolah melaikan mereka ikut dengan sudaranya untuk berkerja di pembangunan gedung atau rumah sebagai kuli bangunan.

Meskipun demikian banyak warga yang memiliki usaha rumahan seperti berniaga atau berdagang adapula berkebun, dan berkerja sebagai guru. Namun karena Desa situ ilir ini sebagai besar nya memiliki lahan pertanian atau alam, yang dibuat sebagai potensi alam yang bisa digunakan sebagai sarana pekerjaan untuk masyarakat, seperti Danau Buatan dan Arum Jeram. Ada beberapa macam potensi alam yang ada di Desa Situ Ilir Kecamatan 
Cibungbulang Kabupaten Bogor diantaranya adalah terdapat Danau Buatan, Sungai untuk Arum Jeram, Peswahan yang luas. Potensi ini menjadi sarana pekerjaan untuk masyarakat Desa Situ Ilir adapun beberapa sarana pekerjaan untuk masyarakat Desa Situ Ilir adalah Sebagai Berikut :

1. Pertanian

Sebagian Besar Sawah dimiliki oleh masyarakat Desa Situ Ilir, namun memang memperkerjakan Orang Desa Situ Ilir Sendiri.

2. Pariwisata

Wilayah tidak memiliki banyak tempat wisata, namun masyarat Desa Situ Ilir berinisiatif untuk membuat tempat wisata di Desa ini untuk menunjang perekonomian rakyatnya itu sendiri. Seperti Taman Wisata Air Gunung Handeulem, Arum Jeram, Taman Air Cinta,

3. Perkebunan

Komoditas utama perkebunan yang dihasilkan adalah Palawija, Terong, Jagung, Tomat, Kol Dan lain-lain

Keadaan aksebilitasi atau jalan menuju Desa Situ Ilir sudah Baik sebagi besar sudah di Beton dan Aspal, ada juga bebera wilayah RW yang masih berbatu namun hasil survey yang kita dapatkan bahwa tahun ini sudah bisa diperbaiki jalan tersebut.

\section{Keadaan Geografis}

Desa situ ilir adalah desa yang berkedudukan di kecamatan Cibungbulang Kabupaten Bogor, dalam perkembangan banyak menorehkan sejarah dan keberhasilan dalam bidang pemerintahan, kemasyarakatan maupun pembangunan dari para pemimpinnya. Desa situ ilir adalah salah satu desa yang berlokasi di kecamatan Cibungbulang, dimana sedang dilaksanakan berbagai pembangunan yang bertaraf internasional, yaitu kampong wisata. Yang berwawasab pendidikan. Demikian pula Desa situ ilir memiliki luas lahan kurang lebih 304,218 ha.

Desa situ ilir adalah salah satu desa yang ada diwilayah kecamatan Cibungbulang Kabupaten Bogor dengan letak biografis/ titik koordinat 106.654449 LS/LU -6.630199 BT/BB yang dibentuk pada tahun 1955yang pada waktu itu dijabat oleh Bpk. H. Dahlan, Desa Situ ilir memiliki luas wilayah 304, $218 \mathrm{Ha}$.

Sejak itu sebelum ada dana desa, Desa situ ilir mulai dibangun dengan gotong royong masyarakat yang sangat antusias sehingga timbulah potensi-potensi yang ada di Desa Situ Ilir salah satunya yaitu potensi dibidang pertanian serta potensi lainya yang ada di Desa Situ Ilir Tahun 2017 mencapai 9.804 orang dengan luas area 304,218 Ha sehingga didapatkan kepadatan penduduk sebesar 3. 222 jiwa/km.

\section{METODE PELAKSANAAN}

Dalam pelaksanaan kuliah kerja nyata terintegrasi Universitas Ibn Khaldun Bogor tahun 2018, pendekatan yang kami gunakan dalam kegiatan ini adalah :

1. Metode Participatory Rural Appraisal (PRA)

Merupakan metode yang melibatkan masyarakat mulai dari tahap perencanaan, pelaksanaan, pemanfaatan dan evaluasi. Pendekatan tersebut memungkinkan masyarakat desa saling membagi, menambah dan menganalisis pengetahuan tentang kondisi lingkunganya dalam rangka membuat perencanaan dan tindakan. Dengan demikian metode PRA adalah cara yang 
digunakan dalam melakukan kajian dalam memahami keadaan atau kondisi Desa dengan melibatkan partisipasi masyarakat, atau pengkajian/ penilaian (keadaan) Desa secara Partisipatif.

Dalam kegiatan PRA ini mahasiswa hanya sebagai fasilitator sekaligus motivator dan masyarakatlah sebagai pelaksananya.

2. Pendekatan Sosial

Pendekatan sosial penulis lakukan dalam beberapa program kegiatan KKN, baik pada tahap perencanaan, pelaksanaan maupun pada tahap evaluasi dalam tahap perencanaan, penekatan sosial dilakukan dengan berusaha melibatkan masyarakat dalam segala jenis kegiatan yang kami selenggarakan, selain ini bersilaturahmi dengan tokoh-tokoh maupun pejabatpejabat yang berada di Desa Situ Ilir. Dengan ini kita bisa mengidentifikasi berbagai ekspetasi, kebutuhan dan permasalahan nyata yang dihadapi masyarakat, sehingga kita dapat menyusun action plan yang lebih tepat dan realistis.

Sedangkan dalam penulisan dan penyusunan laporan akhir menggunakan metode Deskriptif Kualitatif karena pelaksanaan Kuliah Kerja Nyata (KKN) ini bertujuan menggambarkan potensi Desa dan mencari alternative pemecahan masalah sesuai dengan masalah yang berada di wilayah Desa Situ Ilir. Adapun teknik yang digunakan untuk memperoleh daya dan informasi menggunakan teknik :

1. Survey/ Observasi, dengan mengumpulkan data-data penduduk secara langsung ke pedesaan.

2. Wawancara, penulis melakukan wawancara langsung ke tokoh masyarakat dan aparat Desa Situ Ilir.
HASIL DAN PEMBAHASAN

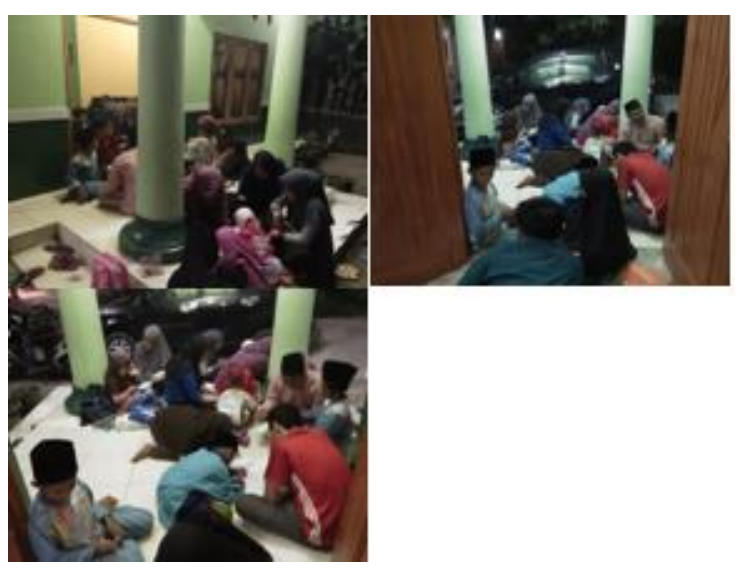

\section{Pengajian Anak-anak}

Program ini bertujuan untuk mengajarkan anak-anak mengenai agama khususnya belajar membaca al-qur'an yang baik dan benar.

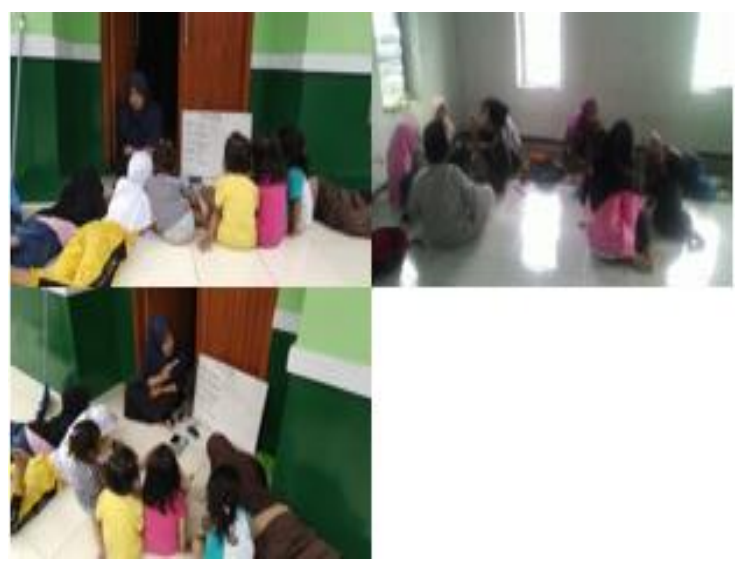

\section{Penyelegaraan Bimbingan Belajar}

Langkah awal yang kami lalui sebelum mengadakan bimbil ini adalah kami melakukan survey ke masyarakat dan sekolah tentang pelajaran yang kurang diminati oleh siswa dan mata pelajaran yang di anggap sulit oleh siswa.

Kami melakukan bimbingan belajar ini agara anak-anak mendapatkan pelajaran Bahasa Inggris serta terbantu dalam pelajaran yang mereka anggap sulit. Anakanak yang mengikuti bimbel ini adalah siswa dari Madrasah Ibtidaiyah. Program bimbingan belajar ini dinyatakan berhasil 90\%. Hasil dari bimbingan belajar ini ialah kebanyakan dari mereka mendapat pengetahuan baru yang pasti belum pernah 
diajarkan disekolah mereka. Dan mereka merasa sangat terbantu dengan diadakannya bimbingan belajar ini.

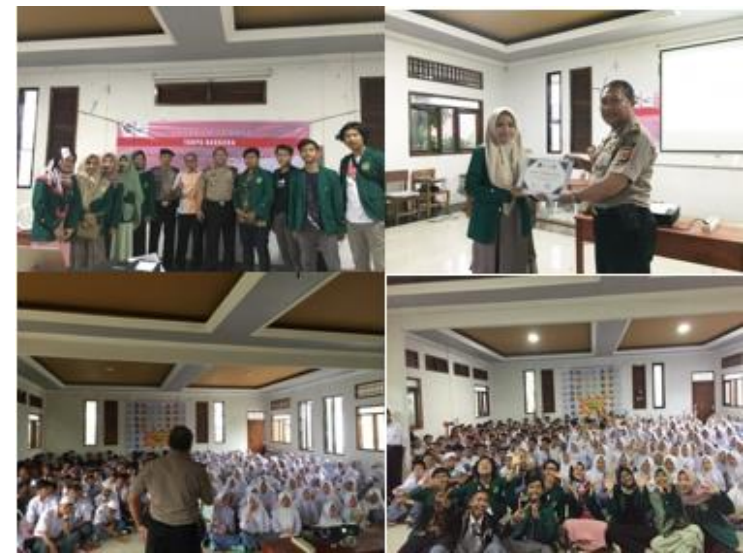

\section{Sosialisasi Hukum Penyalahgunaan}

Narkoba dan Pencegahan Pergaulan

\section{Bebas}

Sosialisasi ini bertujuan untuk meminimalisir sesuatu yang buruk terjadi terhadap generasi-generasi penerus bangsa apalagi mengenai Narkoba dan Pergaulan bebas yang sangat marakk terjadi. karena kondisi saat ini memang sangat mengkhawatirkan apa lagi untuk anakanak remaja yang masih labil dan mudah sekali untuk dibawa ke jalan salah. Sosialisasi ini di isi oleh pemateri dari POLSEK CIBUNGBULANG dan peserta yang hadir lebih dari 250 orang peserta Siswa/I SMA dan SMK Al- Aulia.

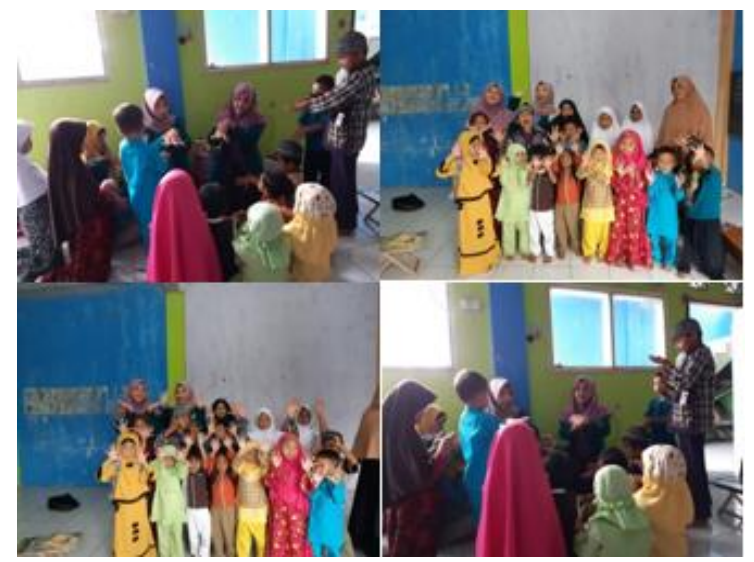

\section{PHBS Cuci Tangan}

Penyuluha tersebut dilaksanakan agar anak-anak mampu menjadikan budaya mencuci tangan sejak dini. Anak-anak yang mengikuti penyuluhan ini yaitu anak- anak TPA Madistra. Program penyuluhan Cuci Tangan ini dinyatakan berhasil karena anak-anak sangat berantusian dalam mengikuti program ini. Hasil yang diperoleh dari penyuluhan ini adalah anakanak mendapat pengetahuan baru bagaimana cari mencuci tangan yang baik dan benar, dan untuk mengetahui manfaat atau fungsi dari mencuci tangan yang baik dan benar ini. Menurut Eska dalam Jurnal Abdi Dosen Pemberdayaan kesehatan merupakan kegiatan penambahan pengetahuan yang diperuntukan bagi masyarakat melalui penyebaran pesan.

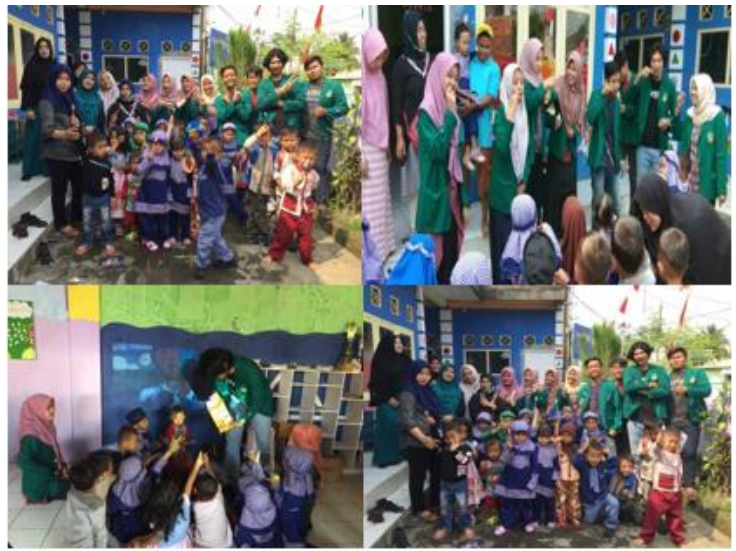

Cara Menggosok Gigi yang Baik dan Benar

Penyuluhan gosok gigi ini dilakukan agara anak-anak mampu memahami bahwa menggosok gigi merupan satu hal yang penting dalam proses pencernaan makanan. Jika gigi mengalami gangguan, akan terganggu pula proses pencernaanya, namun hal tersebut dapat dicegah dengan rutin menggosok gigi minimal $2 \mathrm{x}$ sehari. Dalam kegiatan ini kami membagikan 60 sikat gigi kepada anaka-anak TK agar mereka dapat mempraktekanya dirumah mereka masing-masing . anak-anak yang mengikuti kegiatan ini sangat semangat dan antusias. Hasil yang diperoleh dari kegiatan ini ialah anak-anak dapat mengetahui tentang bagaimana cara menggosok gigi yang baik dan benar serta 
mengetahui bahaya bagi mereka yang malas menggosok gigi.

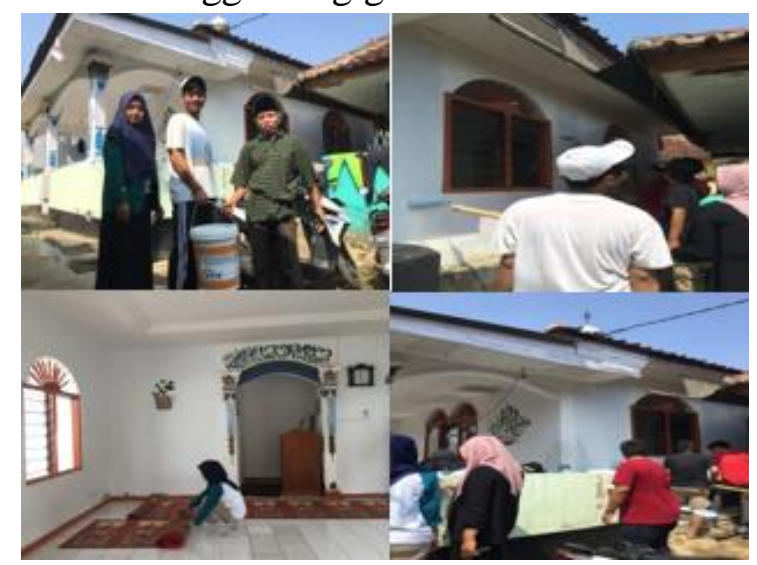

Gotong Royong dan Pengecatan Ulang Masjid

Kegiatan ini adalah salah satu kegiatan social untuk meperbaiki kondisi salah satu majlis atau musholah yang ada di Desa Situ Ilir yaitu mausholah $\gg>>>$ yang ada di RW 05 Desa Situ Ilir. Guna menjadikan masyarakat lebih peduli lagi terhadap masjid yang ada di lingkunganya agar bisa lebih nyaman saat digunakan atau saat beribadah.

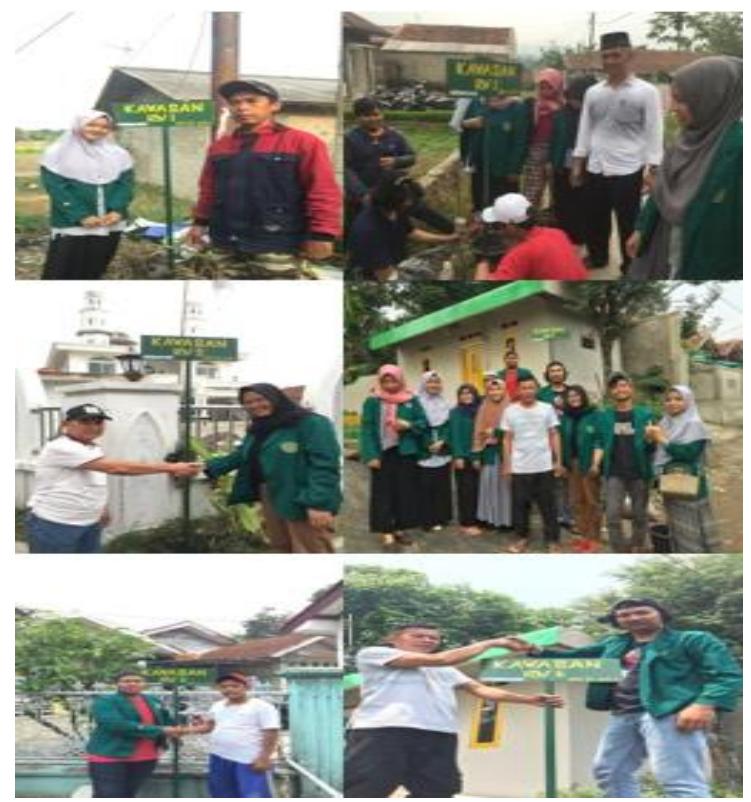

Pembuatan Papan Nama Kawasan RW

Masing-masing plang di pasang dan diterima oleh Ketua RW masing-masing. Dan 1 plang yaitu plang RW diterima dan dipasang oleh Bapak kepala Desa Situ Ilir langsung yaitu Bapak Subhan S.PI. kegiatan ini di lakukan agar masyarakat mengetahui kawasan-kawasan RW masing-masing yang ada di Desa. Juga menjadikan petunjuk letak kawasan RW di Desa Situ Ilir guna mempermudah mencara alamat atau letak RW disana.

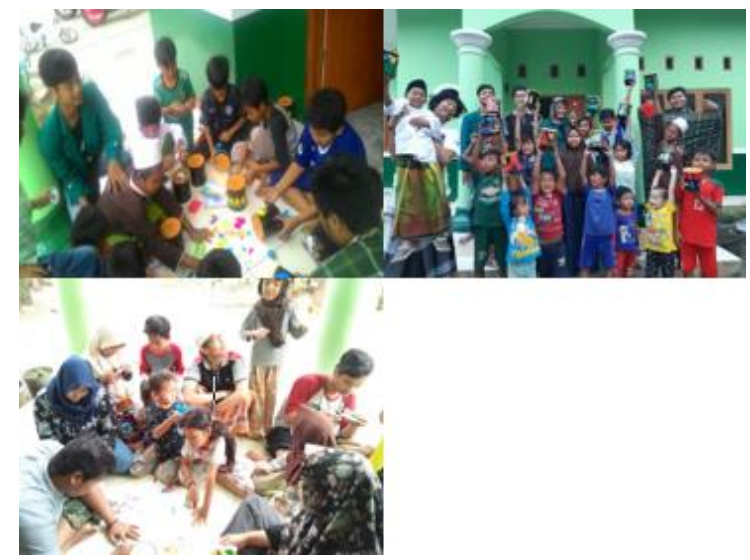

Pembuatan Celengan Kreatif dari Kaleng Bekas (Belajar Menabung Sejak Dini)

langkah awal yang kami lakukan sebelum program ini dilaksanakan yaitu dengan mengumpulkan kaleng-kaleng susu bekas pakai untuk membuat kreasi celengan dari kaleng bekas. Bahan yang digunakan dalam kegiatan ini ialah cat kaleng, kertas origami. Lalu kertas origami itu dibentuk sesuai keinginan anak-anak setelah itu ditempel di kaleng bekas tersebut. Kegiatan ini bertujuan agar anak-anak semangat dan gemar dalam menabung dan untuk menguji kretifitas anak-anak dalam mengkresikan celengan yang telah dibagikan. Dan kegiatan ini juga berguna untuk memanfaatkan barang-barang bekas yang ternyata masih mempunyai nilai guna yang tinggi. 


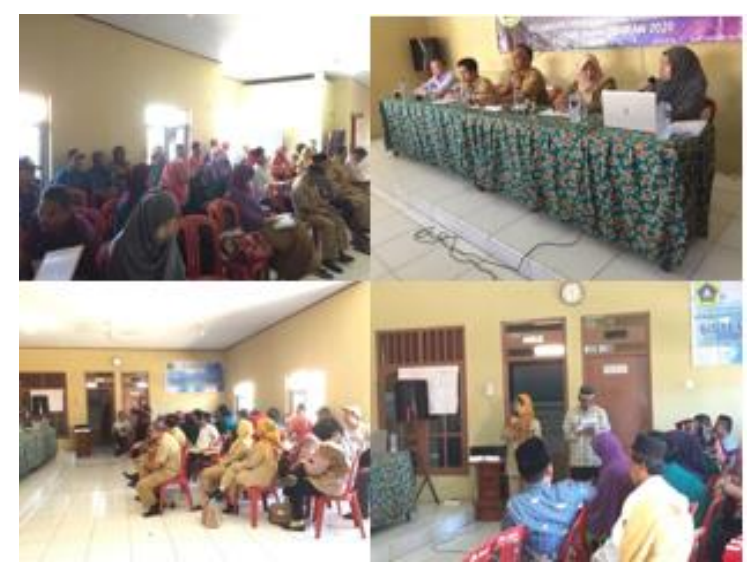

Sosialisasi Pendayagunaan Zakat Infaq Sedekah (ZIS) Guna memenuhi kebutuhan Hidup

Ini adalah salah sat usulan program dari permaslahan ekonomi yang menyangkut desa tersebut. Melihat dari sudut lain dari situasi perekonomian masyarakat desa masih tidak terlepas riba, hal ini dikarenakan masih maraknya Bank Keliling pada desa situ ilir keterpaksaan masyarakat dalam hal ini dikarenakan guna memenuhi kebutuhan hidup pada dasarnya apa yang diperbuat hanya menghasilkan keterpurukan dikarenakan bunga riba tersebut sangatlah tinggi dan terus bertambah. Sosialisasi pendaya gunaan ZIS ini merupakan sebuah solusi dari mahasiswa KKN Kelompok 33 kepada masyarakat yang mana bila di koprasikan simpan pinjam tidak berjalan lancer karena kesadaran masyarakat untuk membayar pinjaman masih minim, maka dari itu Zakat bisa menjadi solusinya. Zakit ini adalah upaya mensucikan harta yang mana harta itu wajib dikeluarkan oleh orang yang beragama islam dan diberikan kepada golongan yang berhak menerimanya. Zakat itu gunanya untuk mengatasi persoalan social seperti pengangguran, kemiskinan dan lain-lain. Guna menghapus kesenjangan social dalam masyarakat.

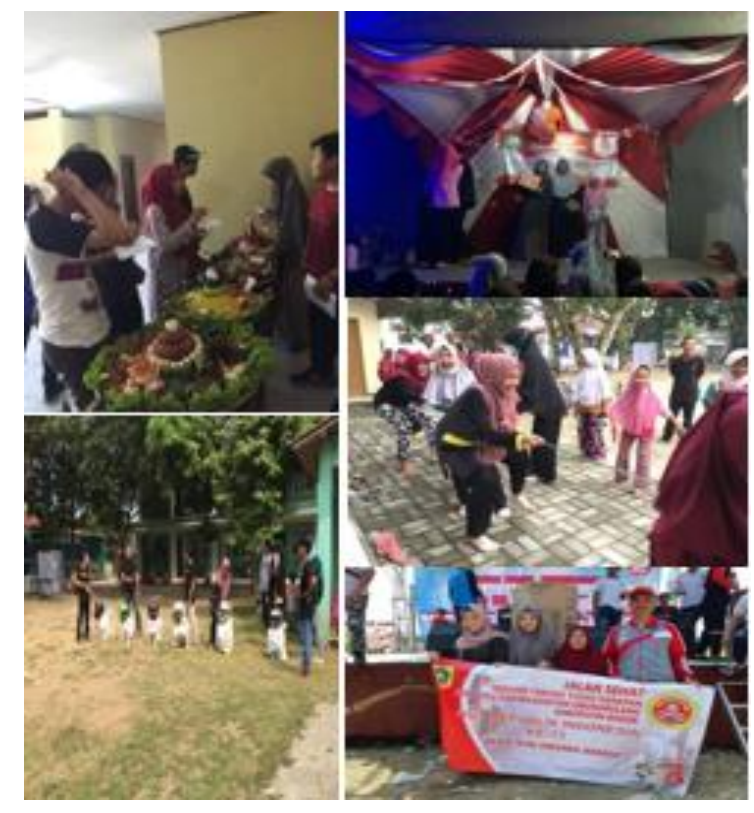

Mengadakan Acara Peringatan HUT-RI untuk menumbuhkan rasa kebersamaan, solidaritas dan semangat patriotism dan nasionalisme dalam diri kami an masyarakat Desa Situ Ilir.

\section{KESIMPULAN}

Di Desa Situ Ilir masih ada fasilatas yang kurang menunjang seperti tempat pembuangan sampah semestara, puskesmas dan adapun jalan yang masih berbatuan. Untuk mendapat fasilitas penunjang kesehatan (Puskesmas) masyarakat harus datang ke desa sebelah yaitu Desa Situ Udik. Untuk persoalan tentang sampah ini yang sangat mengkhawatirkan karena masih banyak masyarakat di beberapa wilayahnya masih membuang sampah ke sungai.

Untuk tingkat pendidikan meskipun Desa ini dikenal sebagai Sentral Pendidikan, namun ada juga masyarakat yang masih belum mementingkan pendidikan. Masih ada juga masyarakat yang putus sekola dan lebih memilih untuk berkerja mengikuti saudaranya menjadi tukang kuli bangunan. 
Selebihnya menurut penulis Desa ini sudah Baik dari segi Struktural Desa, Fasilitas dan kehidupan masyarakat disini sudah cukup baik. Namun memang ada beberapa hal yang perlu sangat diperhatikan yaitu Pengadaan Puskesman, perbaikan jalan dan Pendidikan bagi keluarga yang kurang peduli terhadap pendidikan.

\section{Dampak Bagi Masyarakat}

Dalam program-program kerja yang akan laksanakan dampak yang dapat diperoleh masyarakat antara lain :

a. Bidang Pendidikan

1. Pengajian Anak-anak

Manfaat yang diperoleh yaitu agar pendidikan agama khususnya cara membaca al-quran yang baik dan benar dengan mengetahui hukum tajwidnya kepada anak-anak di lingkungan RW02/02.

2. Penyelenggaraan Bimbingan Belajar Manfaat penyelenggaraan bimbingan belajar ini adalah anak-anak dapat termotivasi untuk melanjutkan pendidikanya kejenjang yang lebih tinggi, juga membantu anak-anak mendapatkan ilmu yang lebih selain di sekolah. Membantu anak dalam mengerjakan PR. Anak-anak juga mendapat metode dan system pengajaran yang berbeda dengan di sekolah. Selain itu anak-anak dapat meningkatkan kemampuan dalam menghaapi kesulitan dalam memahami pelajaran.

3. Sosialisasi Hukum Penyalahgunaan Narkoba dan Pencegahan Pergaulan bebas

Sosialisasi hukum mengenaik penyalahgunaan narkoba dan pergaulan bebas ini berguna untuk menambah pengetahuan tentang bahayanya pergaulan bebas sampai dengan pengenalan obat-obat terlarang serta mengenal tentang hukum apabila terjerumus kedalamnya. Sosialisasi ini bermanfaatuntuk meminimalisir pergaulan bebas bagi remaja di Sekolah Al-aulia.

b. Bidang Kesehatan dan Lingkungan

1. PHBS Cuci Tangan

Kegiatan ini dapat bermanfaat untuk ilmu pengetahuan yang baru untuk anak-anak dna ibu-ibu, bagaimana pentingnya mendidik anak untuk selalu mencuci tangan dan untuk mengajarkan anak berprilaku bersih khususnya dalam hal mencuci tangan dengan baik dan benar.

2. Cara menggosok gigi yang baik dan benar

Kegiatan ini juga bermanfaat untuk mengajarkan anak menggosok gigi dengan baik dan benar, untuk mengetahui juga pentingnya mengosok gigi minimal $2 x$ sehari dan untuk mengetahui dampak negative apabila malas menggosok gigi.

3. Gotong Royong dan Pengecatan Ulang Majlis/ Musholah

Kegiatan ini merupakan kegiatan social yang dijalankan oleh peserta kkn dengan dibantu oleh warga sekitar musholah. Kegiatan ini berguna untuk menumbuhkan kembali semangat gotong royong dalam menjalankan sesuatu juga ajang silaturahmi dengan masyarakat sekitar. Kegiatan ini juga bermanfaat untuk memperbaiki musholah yang kurang terawatt agar lebih nyaman dalam menjalankan ibadahnya.

4. Pembuatan Papan Nama Kawasan RW (Plang) 
Pembuatan papan nama ini bermanfaat agar masyarakat lebih tau kawasan-kawan RW di Desa Situ Ilir. Juga mempermudah masyarakat dalam ataupun luas desa dalam mencari alamat di Desa Situ Ilir.

c. Bidang Ekonomi

1. Menabung Sejak Dini

Kegiatan penyuluhan ini berguna untuk mengajarkan anak-anak untuk rajin menabung sejak gini. Dan juga mengasah kreatifitas anak-anak dalam membuat celengan kreatif tersebut. Hal ini juga berguna dalam memanfaatkan barang bekas yang masih bisa dipakai dan memiliki nilai jual yang cukup tinggi.

2. Sosialisasi Pendayagunaan Zakat Infaq Sedekah (ZIS) Guna memenuhi kebutuhan Hidup

Sosialisasi pendayagunaan Zakat, Infaq dan sodaqoh (ZIS) ini bertujuan untuk memberi pengetahuan kepada masyarakat Desa Situ Ilir agar mengenatahuiin apa saja kegunaan ZIS ini dalam memenuhi kebutuhan hidup Mayarakat. Dan kegiatan ini adalah salah satu solusi yang ditawarkan oleh Mahasiswa KKN 33 untuk memperbaiki kehidupan ekonomi masyarakat Desa Situ Ilir.

\section{REFERENSI}

Adimihardja, K. \& H. H., 2003. Participatory Research Appraisal: Pengabdian dan Pemberdayaan Masyarakat. Bandung: Penerbit Humaniora.

Banu, Fredik, 2002. Ekonomi Kerakyatan dan Pemberdayaan Ekonomi Rakyat: Suatu Kajian Konseptual, www.ekonomirakyat.org/artikel_3.ht $\underline{\mathrm{m}}$

Eska Perdana Prasetya (2017), Pemberdayaan Masyarakat Tentang Kesehatan, Pendidikan Dan Kreatifitas, Jurnal Abdi Dosen

Joyce, Bruce dan Weil, Marsha. (1996). Models of Teaching. Boston: Allyn and Bacon.

Sugiyono. 2005. Metode Penelitian Administrasi. Bandung: Alfabeta 